\title{
The Genesis of the Male Nuclei in Lilium.
}

\author{
BY
}

E. J. WELSFORD, F.L.S.,

Assistant in the Department of Plant Physiology and Pathology, Imperial College of Science.

\section{With Plates XVI and XVII.}

A PAPER was published in I9I3 by Professor V. H. Blackman and the A author, giving an account of fertilization in Lilium auratum and Lilium Martagon. ${ }^{1}$ As a good deal of material remained over from this investigation, it seemed worth while to add to it and to undertake a study of the development of the male nuclei.

It is a pleasure to take this opportunity of most sincerely thanking Professor Blackman for his generosity in handing over the material to the author.

The earliest stage examined was that in which the young pollen-grain of Lilium auratum contains a single nucleus, lying near the centre of the cell; its protoplasm is finely vacuolate throughout. Preparatory to the first post-meiotic division, the nucleus moves to one side of the pollen-grain and enters upon a spireme phase. The various stages of division follow one another rapidly (Pl. XVI, Figs. I-3), and result in the formation of two similar nuclei which lie close to each other against the wall of the grain (Fig. 4). The innermost or tube nucleus now moves towards the centre of the cell, after which its membrane becomes more clearly defined and its outline is often seen to have become irregular, so much so that it is sometimes lobed, a condition, however, more commonly found after the nucleus has passed some little way down the pollen tube. Meanwhile the membrane of the generative nucleus has become clearly visible, and the cytoplasm immediately surrounding it is seen to be so dense as to form a differentiated area. The cytoplasm of the pollen-grain, at this time, is very vacuolate, the walls of the meshes appearing to be formed of densely granular protoplasm (Fig. 6). The preparations suggest that the dense appearance of the generative protoplasm is due to the granular matter which is concentrated in this part of the grain, whilst the remainder becomes more vacuolate. At first it is

1 Blackman and Welsford: Fertilization in Lilium. Ann. of Bot., vol. xxvii, I9I3, p. 3 .

[Annals of Botany, Vol. XXVIII. No. CX. April, 19I4.] 
only these vacuoles which mark the limit of the generative cell (Fig. 6), but later on a membrane is differentiated (Fig. 7). The generative cell takes the shape of that part of the pollen-grain wall against which it lies, merely bulging out to cover the nucleus. This is more clearly seen in a rather later stage when the generative cell has moved away from the wall. Fig. 8 is a median longitudinal section of the ripe pollen-grain showing the peculiar shape of the generative cell, whilst Fig. 9 is a transverse section showing the nucleus lying in the centre of what appears to be a circular cell.

A deeply staining granule may always be found at either pole of the generative nucleus; they persist till a late stage, probably only disappearing when the cytoplasm of the sperm-cells disintegrates in the embryo sac. They may represent centrosomes, but no traces of spindle fibres were found near them. Granules are also sometimes found lying in a row, midway between the wall of the generative cell and its nucleus. They are extruded from the nucleus (Figs. 6, 7) and were seen to persist in the cytoplasm of the young sperm-cells (Pl. XVII, Figs. 24, 27), where they sometimes form a band-like structure. This is, however, better seen after they have passed from the pollen tube into the embryo sac, and is figured in the previous paper. ${ }^{1}$ Their formation, later appearance, and the fact that they are often, but not always, present, suggest that they may be the vestiges of a blepharoplast.

In the ripe pollen-grain, before the anther has dehisced, the chromatin of the generative cell always stains more deeply than that of the tube nucleus; it is, indeed, already preparing to divide. Nuclear division, however, was never found to occur before germination in Lilium auratum, the nucleus being invariably in the spireme stage when passing into the tube. Material fixed two hours after pollination showed various stages; in some cases the pollen tube was only just growing out, whilst in others the young tube contained a generative nucleus in the anaphase condition. Fig. Io shows a young pollen-grain which has germinated and in which the two nuclei have not passed into the tube. The cytoplasm has a very streaky appearance, indicating that the nuclei are carried out passively by the streaming protoplasm.

Unfortunately the pollen tubes of Lilium auratum at this stage are lying on the stigma and are so twisted that it was found almost impossible to study the stages of nuclear division with accuracy or to make satisfactory drawings of them. The generative cell of Lilium Martagon divides after the pollen tube has grown into the stylar canal, where it keeps a comparatively straight course ; consequently a description of the division of the generative cell has been given of this plant instead of Lilium auratum. Sufficient preparations, however, were obtained of Lilium auratum to show that the stages of division are very similar in the two species.

1 Loc. cit., Blackman and Welsford, Plate XII, Fig. 6. 
Soon after the generative cell of Lilium Martagon has passed into the tube its nucleus enlarges, often almost hiding the cytoplasm; in Pl. XVI, Fig. I I it is seen to be much spread out and to be lying over one of the polar granules. The outline of the generative cell is still clearly visible at the stage shown in Fig. 12 before the split thread has divided to form the chromosomes. From this time the generative cell increases greatly in size and becomes less clearly marked, though it is differentiated from the more vacuolate protoplasm surrounding it. After the cytoplasm has spread out and before the chromosomes pass into the metaphase the chromatin material is often found to lie in a curved mass suggesting a wriggling movement (Figs. I3, I4); later, however, owing to the narrow space of the tube, it spreads out and the twelve longitudinally split chromosomes are formed (Figs. I 5, I6, I7). No spindle fibres were seen at any stage of the division, the twenty-four long thin daughter-chromosomes being massed together as is shown in Pl. XVII, Fig. I9. The chromosomes now separate, and as the two groups move apart each is seen to be surrounded by a separate mass of cytoplasm (Fig. 20). The nuclei of the two male cells pass into the spireme condition and soon assume the curved or humped sausage shape with pointed ends so characteristic of the mature sperm. Nuclei at this stage were found at about $2 \mathrm{~mm}$. from the apex of the stigma and presumably had at least a further Io $\mathrm{mm}$. to travel before reaching the micropyle; this they usually do whilst still surrounded by their cells (Figs. 26, 27), but sometimes the cells are left behind (Figs. 24, 25), or are attached to one end of the nucleus (Figs. 21, 24, 29). Fig. 27 shows two male cells of Lilium auratum about $3 \mathrm{~mm}$. from the apex of the stigma.

Figs. 28, 30, 3I are drawn from pollen tubes dissected from the base of the style of Lilium auratum six days after pollination and about three days before fertilization will take place. The male cells are clearly seen, their nuclei being either curved or straight; the lobed tube nucleus lies a little way in front of the male cells. At this stage the tip of the pollen tube is generally somewhat enlarged and often thickened (Figs. 27, 28). The function of this enlargement was not ascertained; perhaps it may be of use in pushing apart the cells of the micropyle. In Fig. 32 two male cells are seen in the micropyle of Lilium auratum, but in Fig. 33 the nuclei have escaped from their cells and are lying free in the cytoplasm of the pollen tube. The pollen tube actually enters the embryo sac and preserves its shape, at any rate till after fertilization is accomplished, becoming filled with densely staining disintegrating matter after the escape of the two sperm nuclei. This was clearly shown in one preparation where a slight pressure on the cover-slip caused the tube to move slightly and brought its wall into prominence against the vacuolate cytoplasm of the embryo sac. The two male nuclei were invariably found to escape from their cells before leaving the pollen tube to pass across the embryo sac. 
The male nuclei thus, either with or without their cells, are seen to travel from 10 to $16 \mathrm{~mm}$. in five days in Lilium Martagon, or from I 2 to $20 \mathrm{~mm}$. in about seven days in Lilium auratum, before they effect fertilization. It is also a noticeable fact that, after the male cells are formed, the protoplasm of the tube no longer has an appearance of active streaming, but instead sometimes looks as if it had been disturbed by a moving body (Figs. 24, 25). The nuclei during their passage down the tube alter slightly ; they never pass into the typical reticulate resting stage, but form a spireme with very few and very delicate cross-connexions (Figs. 24, 25); these connexions become more pronounced in the mature sperm nuclei, and especially so in those nuclei in the later stages of fusion, such as are shown in Figs. I and 6 in the previous paper. It seems, therefore, that the sperm nuclei in Lilium auratum and Lilium Martagon have undoubted motility for a considerable period, and it is suggested that this may be correlated with the fact that there is a minimum of cross-connexions between the chromatin threads during a great part of their existence. The cytoplasm of the male cells soon disintegrates after the loss of the nuclei, and doubtless gives rise to the structures termed ' $\mathrm{X}$-Körper' by Nawaschin. ${ }^{\text {' }}$

The material was fixed in Flemming's fluid of various strengths and in Perenyi's fluid, and was stained with Benda's iron-haematoxylin or with Breinl's stain.

\section{SuMMARY.}

I. The vermiform nuclei of Lilium auratum and Lilium Martagon pass down the pollen tube in male cells and are usually only liberated from their cytoplasm after the pollen tube has entered the embryo sac.

2. The male nuclei are regarded as possessing motility from an early stage of their development.

3. The 'X-Körper' of Nawaschin are shown to be the disintegrating cytoplasm of the male cell

4. The history of the bands of granules sometimes found near the disintegrating cytoplasm suggests the possibility that they may be vestiges of blepharoplasts.

\section{EXPLANATION OF PLATES XVI AND XVII.}

Illustrating Miss Welsford's paper on the male nuclei of Lilium.

\section{PLATE XVI.}

Fig. I. Lilium auratum. Single nucleus of pollen-grain preparing for division. $\quad \times$ I,200.

Fig. 2. Lilium auratum. Later stage of same. $\times 1,200$.

Fig. 3. Lilium auratum. Ditto, showing the twenty-four daughter chromosomes separating from each other. $\times 1,200$.

1 Nawaschin, S.: Näheres über die Bildung der Spermakerne bei Lilium Martagon. Annales du Jard. Botan. de Buitenzorg, $2^{\mathbf{e}}$ sér., Suppl. iii, I910. 


\section{Welsford.-The Genesis of the Male Nuclei in Lilium.}

Fig. 4. Lilium auratum. The tube and generative nuclei lying close together and showing no differentiation. $\times 800$.

Fig. 5. Lilium auratum. The tube nucleus has moved towards the centre of the cell; its membrane is not yet clearly defined. The formation of the generative cell has begun. $\times 800$.

Fig. 6. Lilium auratum. Young generative cell, showing a row of granules. The cell membrane is not yet complete and the cell is delimited by vacuoles. $\times \mathbf{I}, 200$.

Fig. 7. Lilium auratum. Young generative cell, showing the differentiation of cytoplasm and the extrusion of granules from the nucleus. $\times \mathrm{I}, 200$.

Fig. 8. Lilium auratum. Longitudinal section of a pollen-grain, showing the faintly stained tube nucleus and the more deeply stained generative nucleus lying in the generative cell. $\times 800$.

Fig. 9. Lilium auratum. Transverse section of generative cell, showing one of the polar granules. Delicate cross-connexions can be seen between the threads of the spireme. $\times$ I,200.

Fig. Io. Lilium auratum. A generative pollen-grain, showing the tube nucleus and generative cell being carried in a stream of protoplasm towards the tube. $\times 500$.

Fig. II. Lilium Martagon. Generative cell in pollen tube. The nucleus has already begun to enlarge preparatory to division. The two polar granules are shown. $\times 800$.

Fig. I 2. Lilium Martagon. Later stage, showing the longitudinally split thread. The generative cell is clearly shown. $\times 800$.

Fig. I3. Lilium Martagon. Later stage; the spireme still shows the split in places. The cytoplasm of the generative cell stains very faintly. The curved shape of the spireme is indicated. $\times \mathbf{I}, 200$.

Fig. I4. Lilium Martagon. About the same stage as Fig. I3. $\times$ I, 200.

Fig. I 5. Lilium Martagon. Shows the twelve split chromosomes lying in the generative cell. $\times \mathrm{I}, 200$.

Fig. 16. Lilium Martagon. Shows the twelve split chromosomes lying in the generative cell. $\times \mathrm{I}, 200$.

Fig. I7. Lilium Martagon. Ditto. $\times 800$.

Fig. I8. Lilium Martagon. Chromosome 7 from Fig. 7 . $\quad \times$ I,800.

\section{PLATE XVII.} $\times 800$.

Fig. 19. Lilium Martagon. Metaphase in generative cell; one of the polar granules is shown.

Fig. 20. Lilium Martagon. Anaphase. The two groups of chromosomes are lying in the male cells. $\times 800$.

Fig. 21. Lilium Martagon. A later stage. $\times 800$.

Fig. 22. Lilium Martagon. The chromosomes have joined up. The generative cytoplasm is very thin and spread out. $\times \mathrm{I}, 200$.

Fig. 23. Lilium Martagon. A rather later stage; the spireme thread is thickening and the whole nucleus is beginning to show a curvature. $\times \mathbf{I}, 200$.

Fig. 24. Lilium Martagon. Two male nuclei at a slightly later stage than that shown in Fig. 23. One of the nuclei has moved away from its cytoplasm. Both masses of cytoplasm show a more or less band-like group of granules. These nuclei are about $8 \mathrm{~mm}$. from the top of the ovary. $\times 800$.

Fig. 25. Lilium Martagon. A rather older male nucleus, showing its curved, almost spiral shape. The protoplasm has a disturbed appearance. This nucleus is also about $8 \mathrm{~mm}$. from the top of the ovary. $\times 1,800$.

Fig. 26. Lilium auratum. Part of a pollen tube dissected from the base of the style. The two male cells are clearly seen, each with its curved nucleus and numerous granules. The tube nucleus is also shown. $\times 500$.

Fig. 27. Lilium auratum. Two male cells in a bent-over pollen tube about two $\mathrm{mm}$. from the apex of the stigma. $\times \mathrm{I}, 200$.

Fig. 28. Lilium Martagon. Two male cells in the tube; one of the nuclei has almost parted from its cytoplasm. $\times 800$.

Fig. 29. Lilium Martagon. A male nucleus and its faintly stained cytoplasm lying in the pollen tube. $\times 800$.

Fig. 30. Lilium auratum. A pollen tube from the base of the style, showing the thickened tip, the lobed tube nucleus, and one of the male cells. $\times 500$. 
Fig. 3I. Lilium auratum. A pollen tube from the base of the style, showing the enlarged and thickened tip, the lobed tube nucleus, and the two male cells. $\times 500$.

Fig. 32. Lilium auratum. Semi-diagrammatic drawing of the two male cells and the tube nucleus in the micropyle. $\times 300$.

Fig. 33. Lilium auratum. Upper part of embryo sac, showing the pollen tube with its two male nuclei and the disintegrating cytoplasm of their cells. The egg cell and one of the synergids is also shown, the other has been destroyed by the entrance of the pollen tube. $\times 500$. 
Annats of Botary,
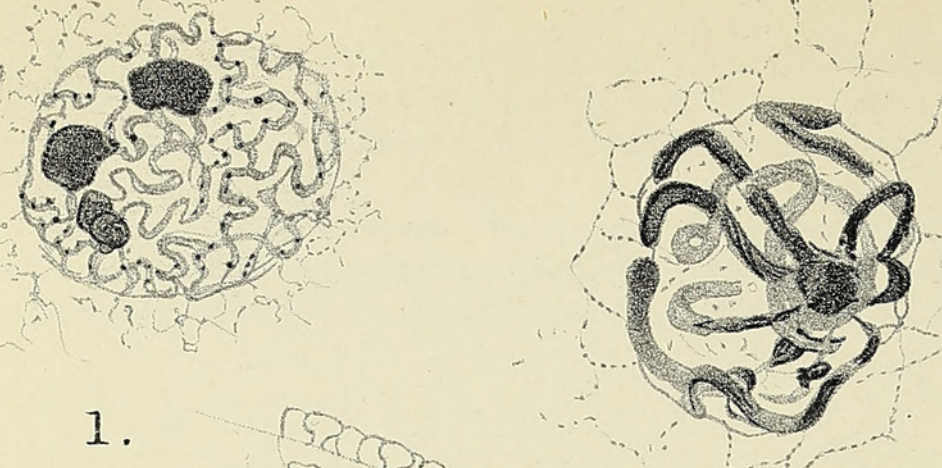

2.
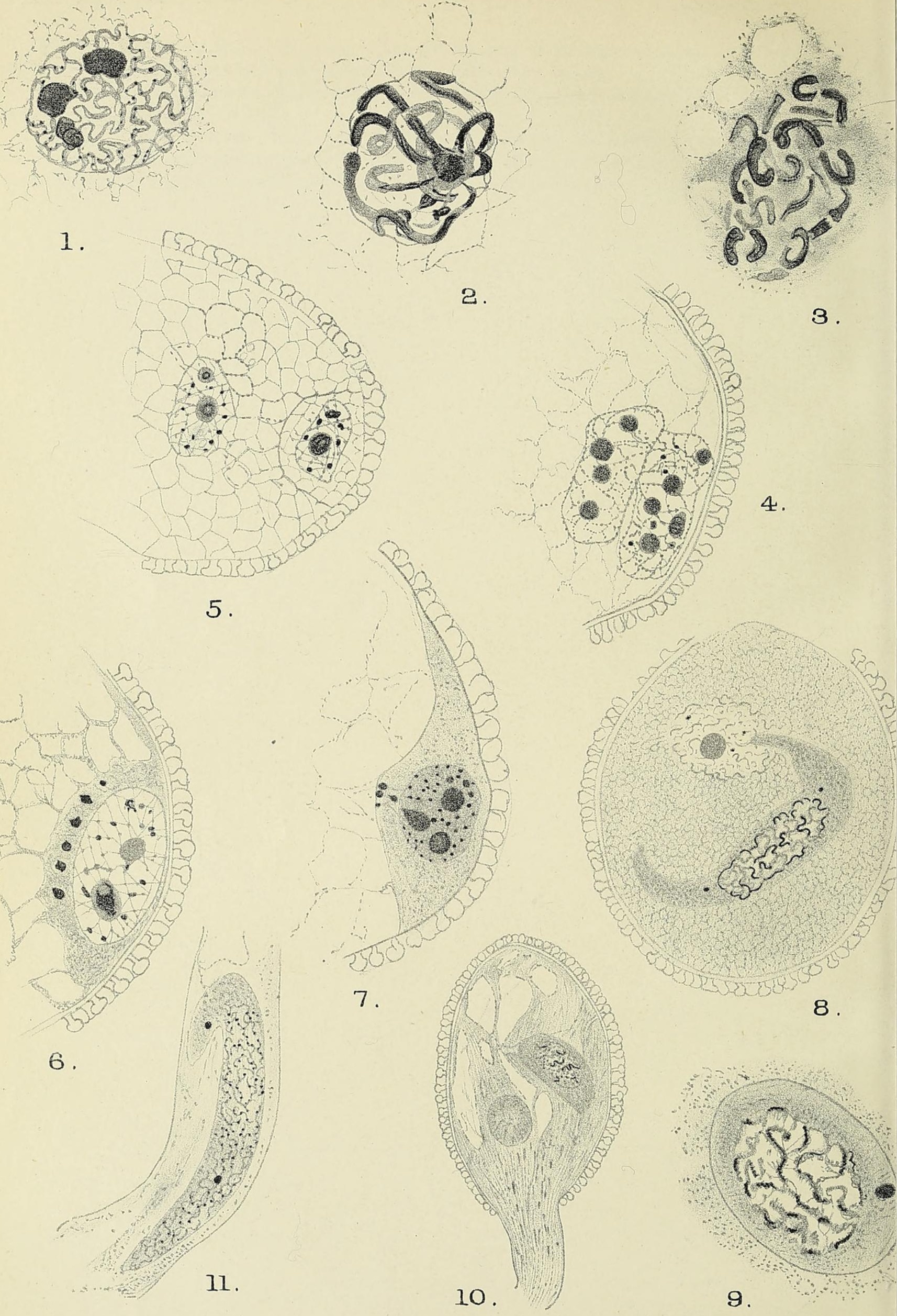

WELSFORD - MALE CELLS IN LILIUM. 
VoZ.XXVIII,PZ XVI.

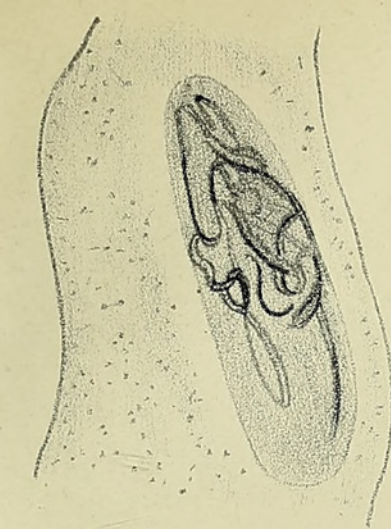

12.

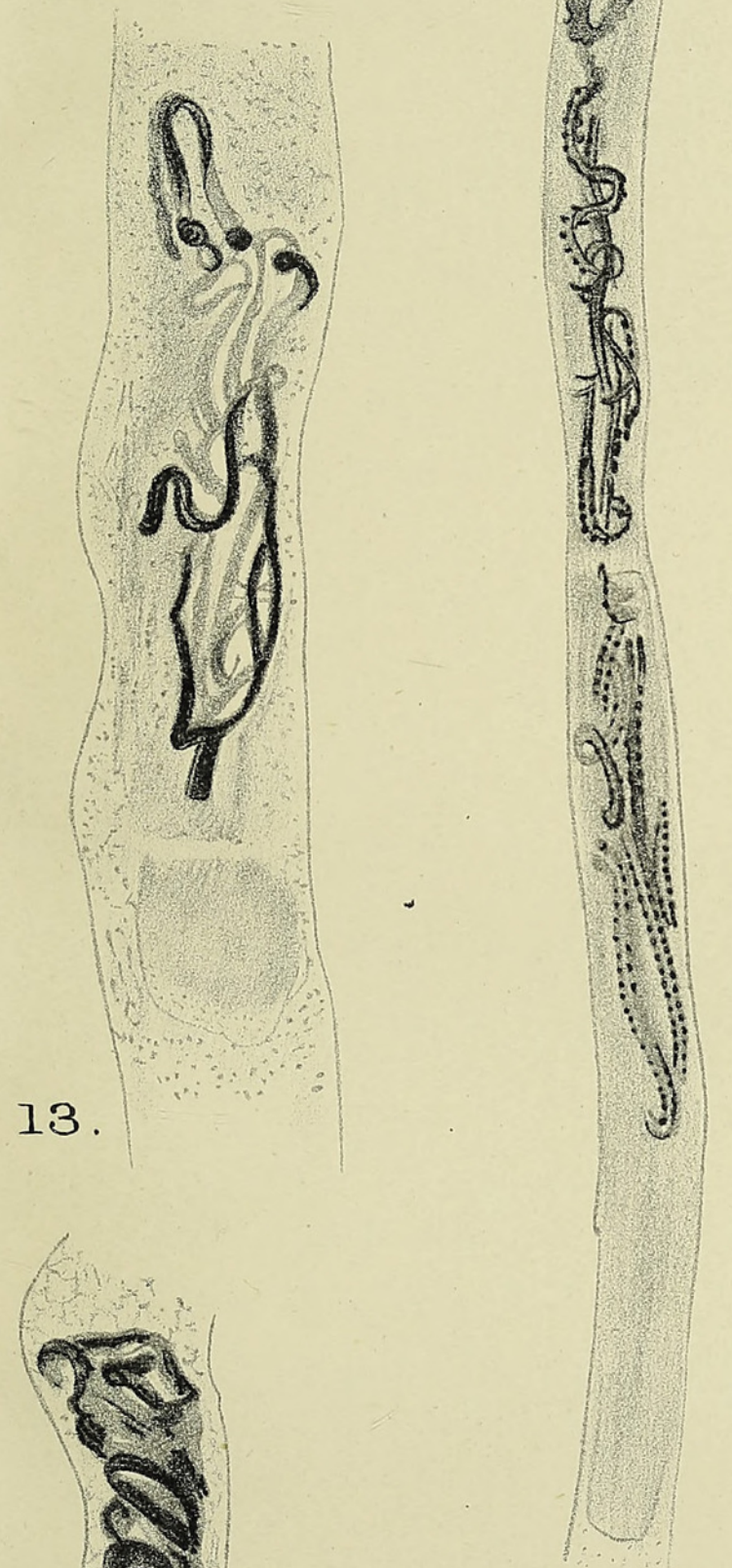

15.

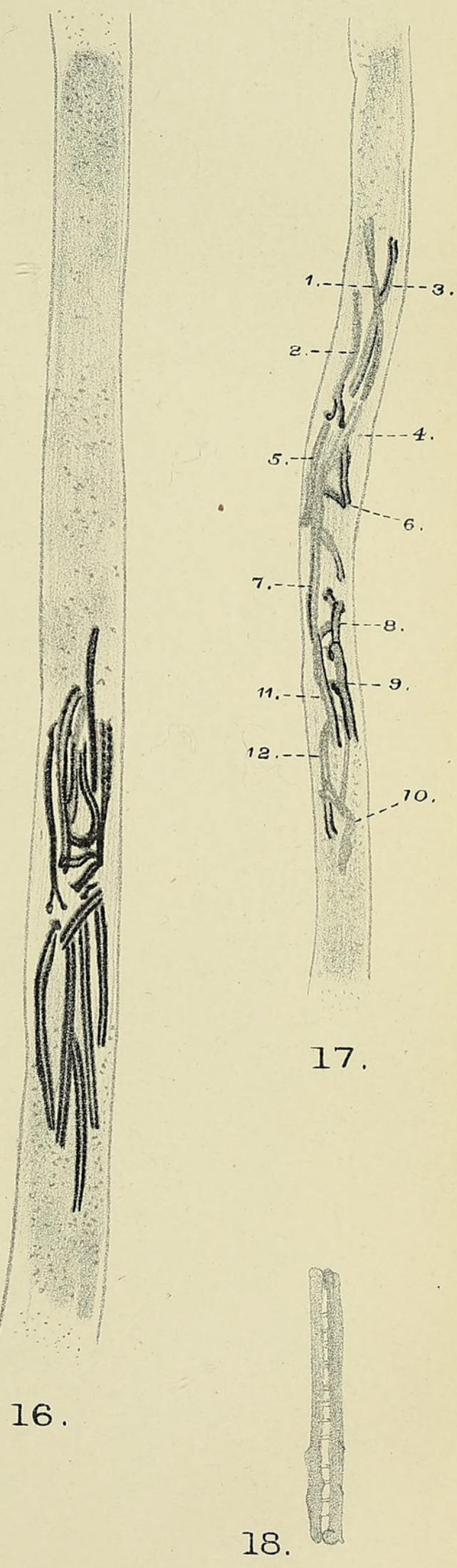

14. 
Annats of Botany,

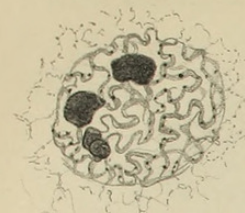

1.

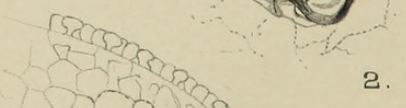

2.
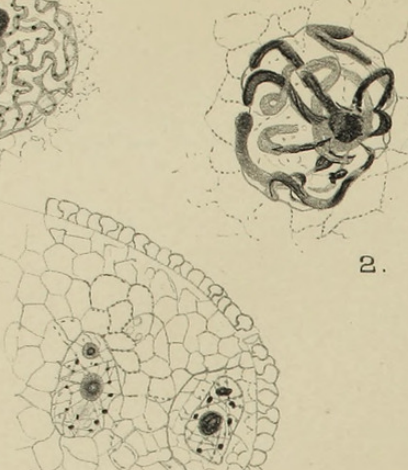

5.

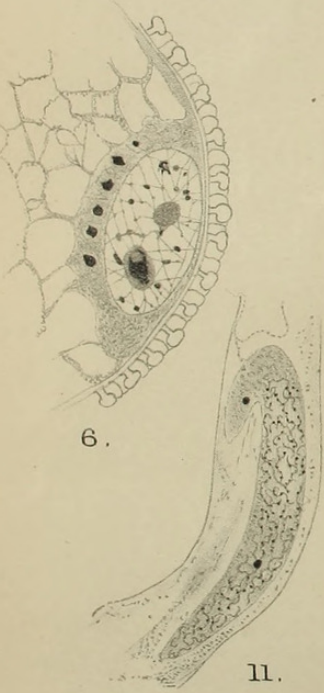

11.

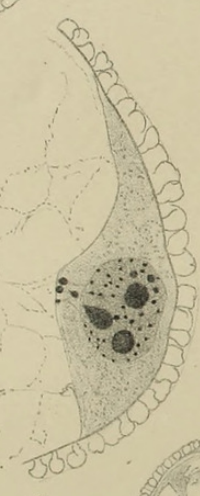

7.
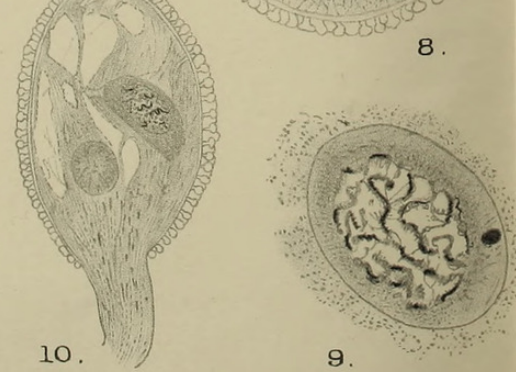

9.
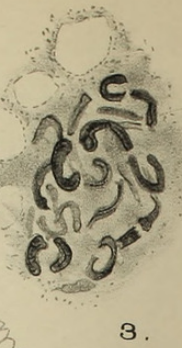

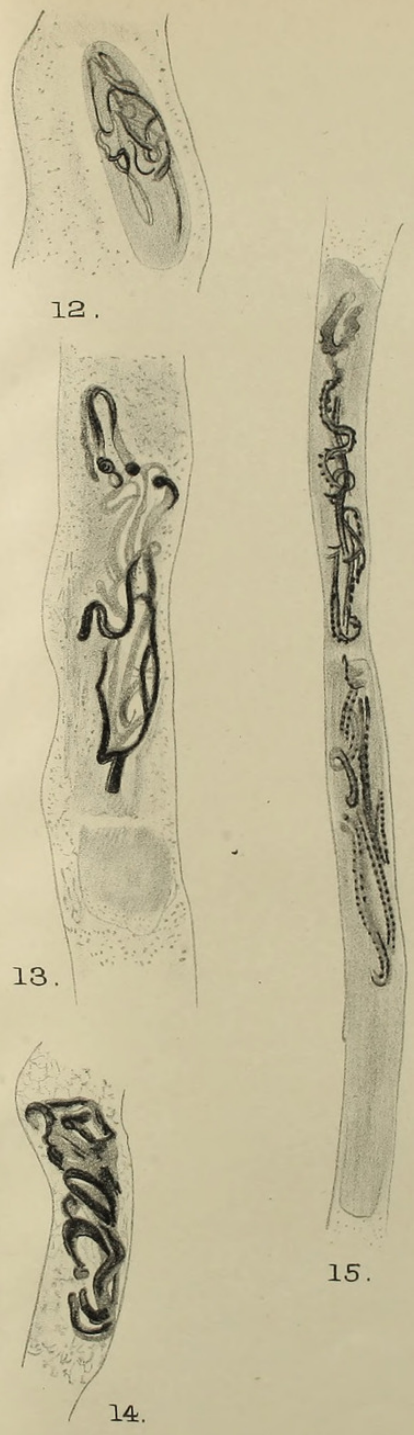

Vol.XXVIII,PZ XVI.

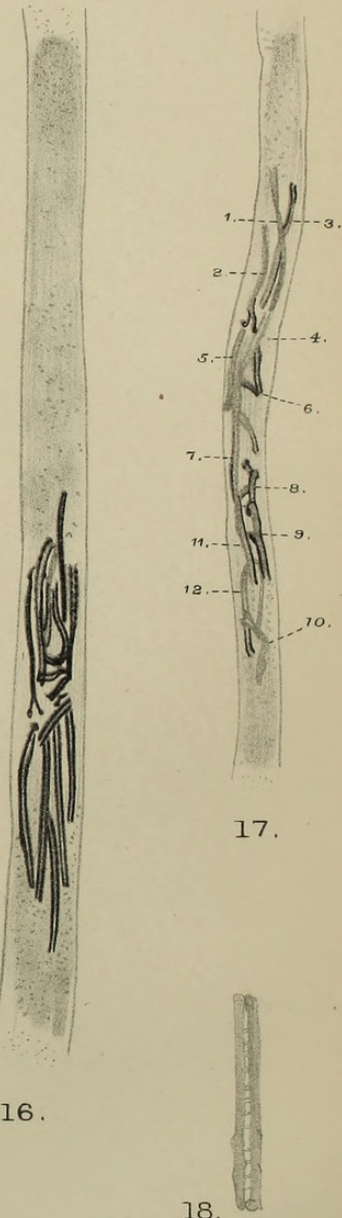

WELSFORD - MALE CELLS IN LILIUM 
Atnrals of Botary,

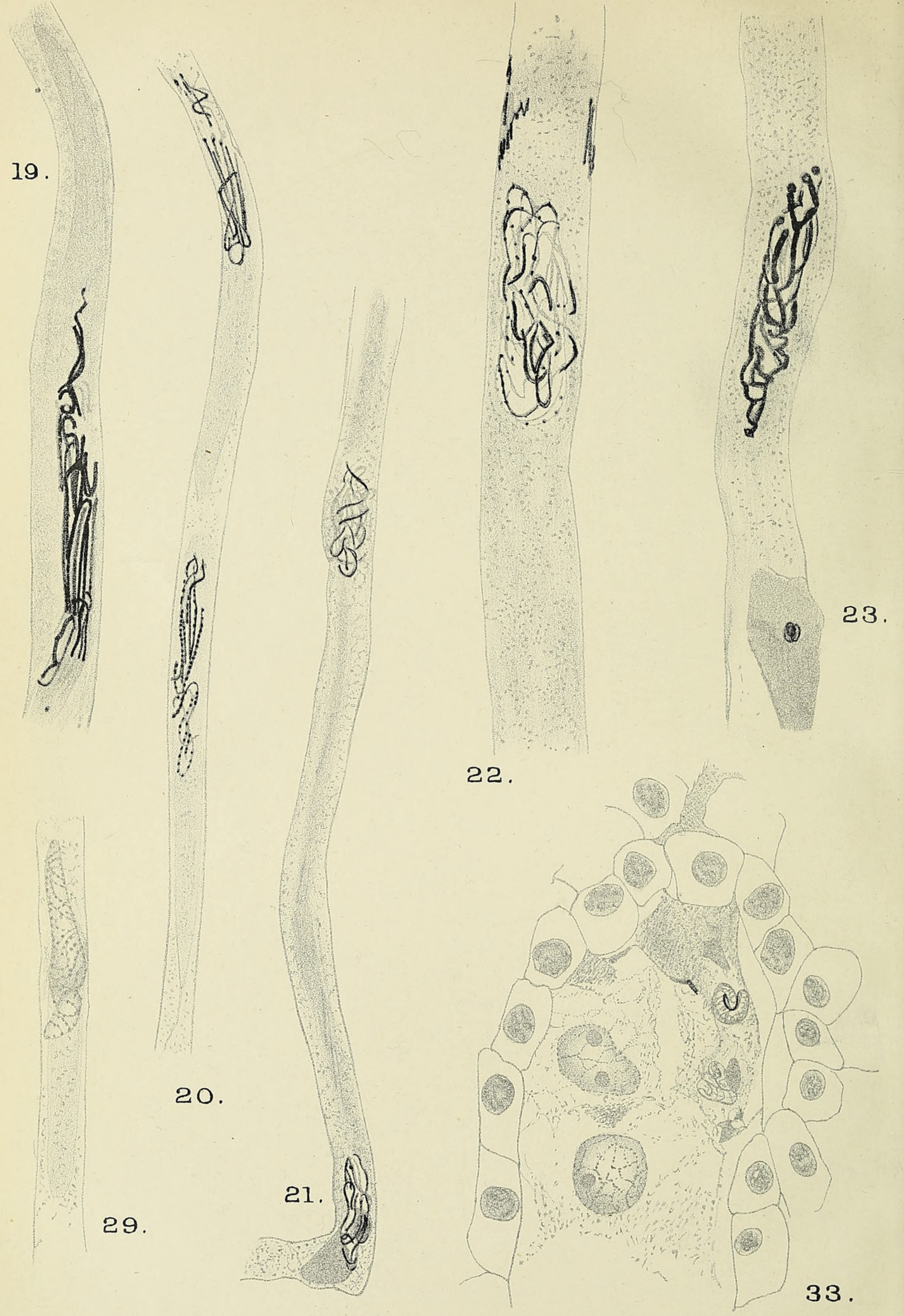

WELSFORD - MALE CELLS IN LILIUM. 

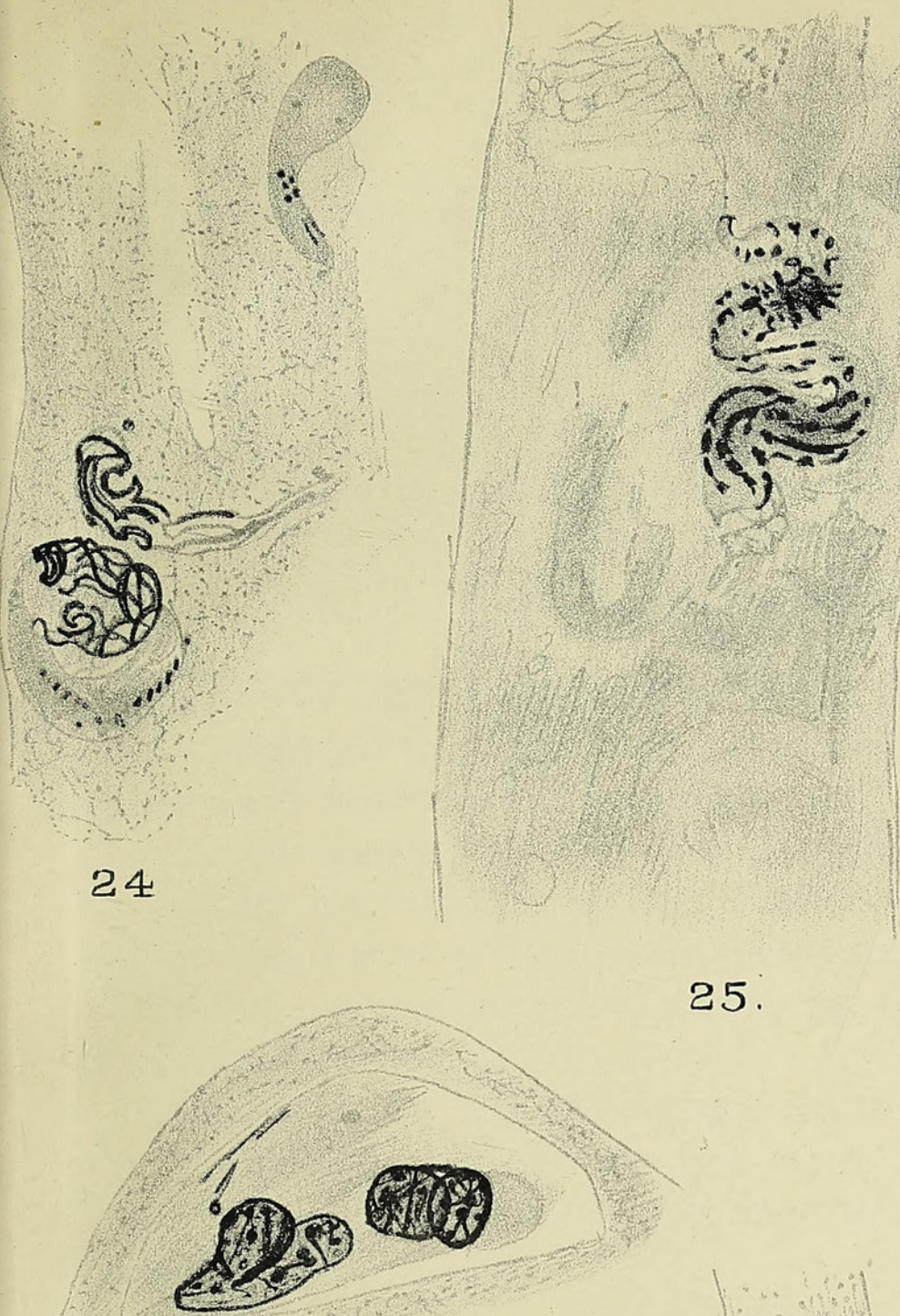

27.

32.
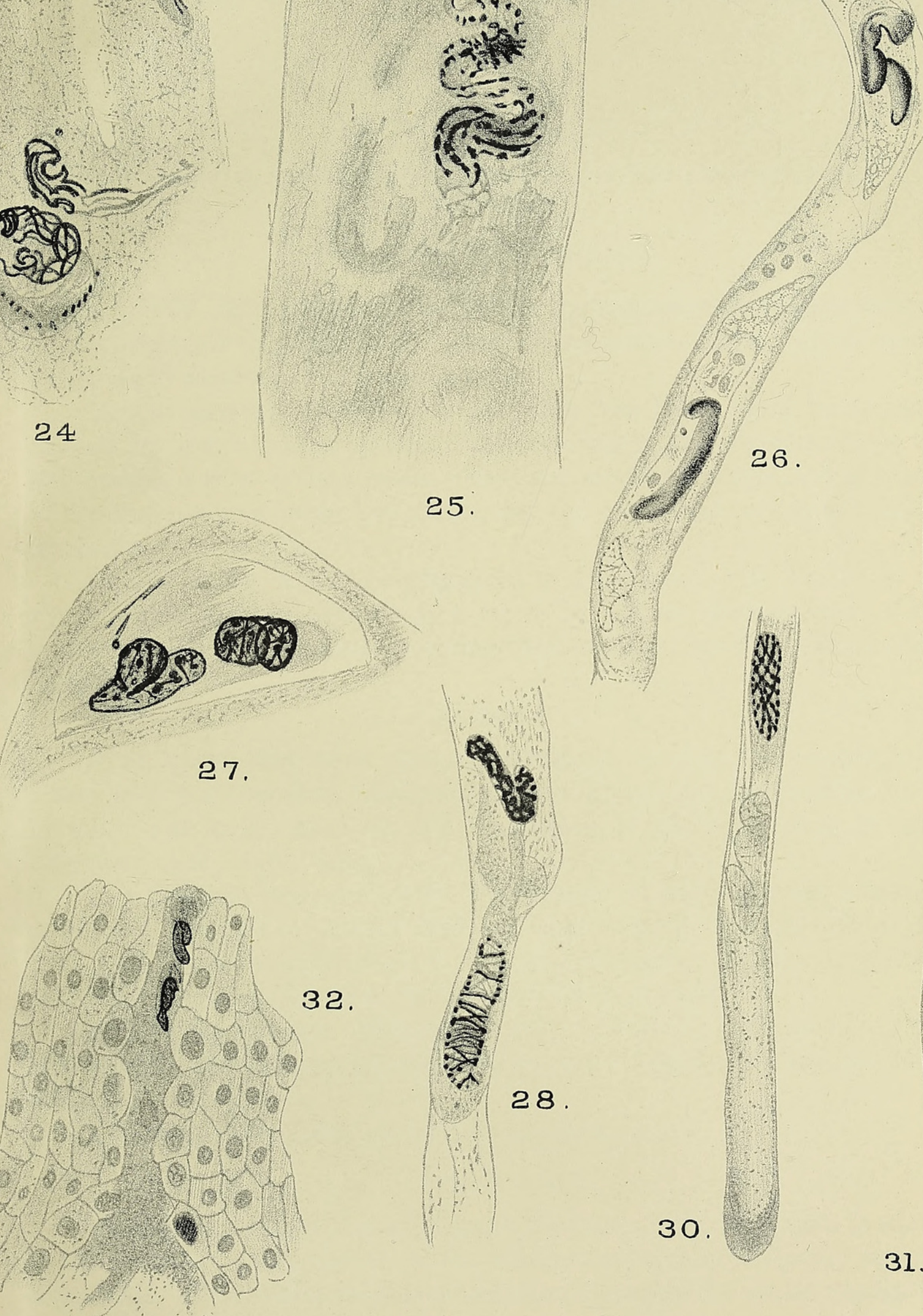

30. 

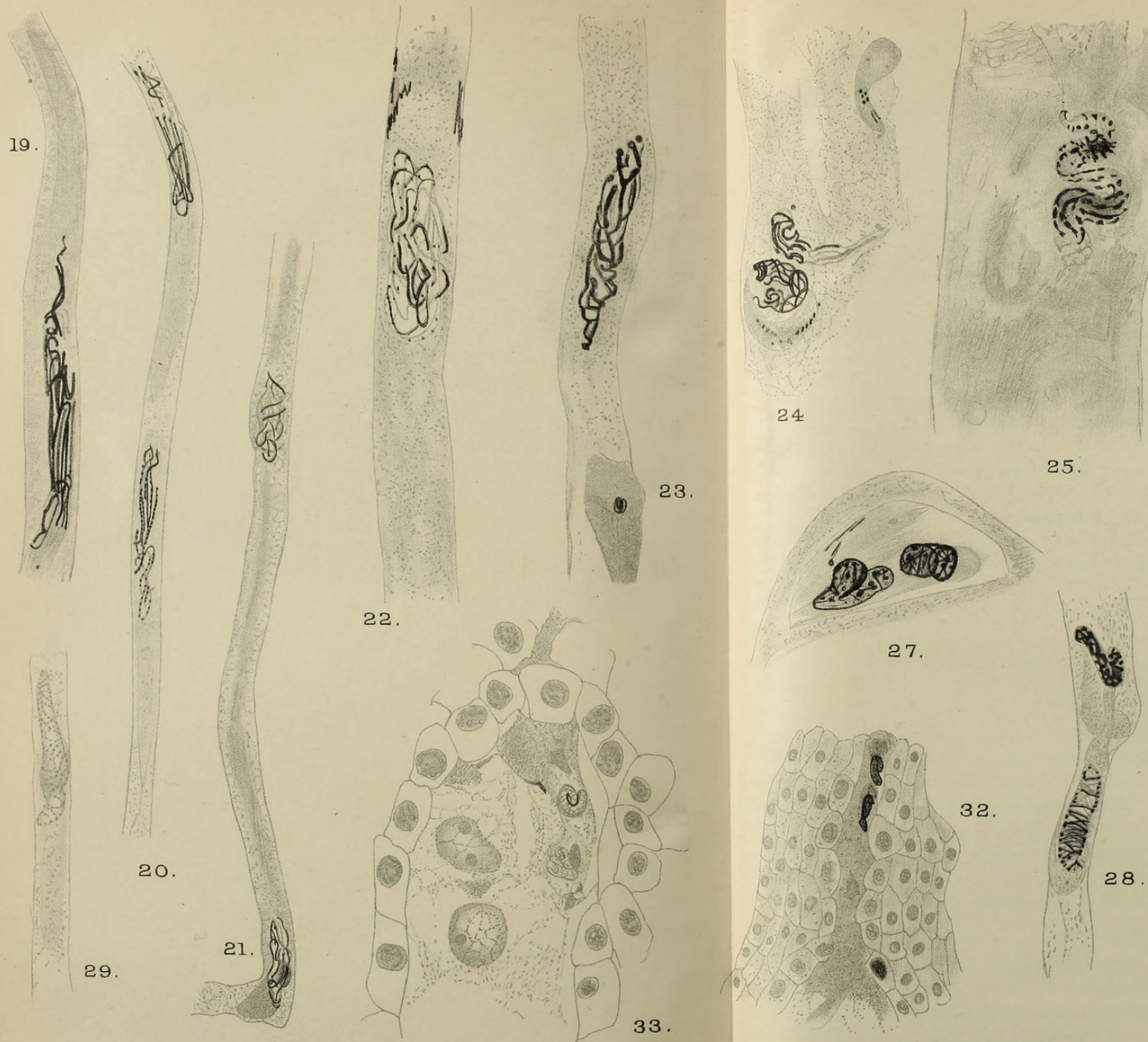

gis

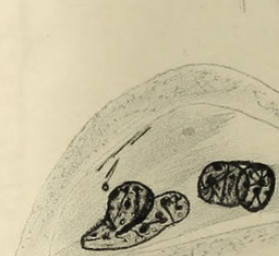

25.
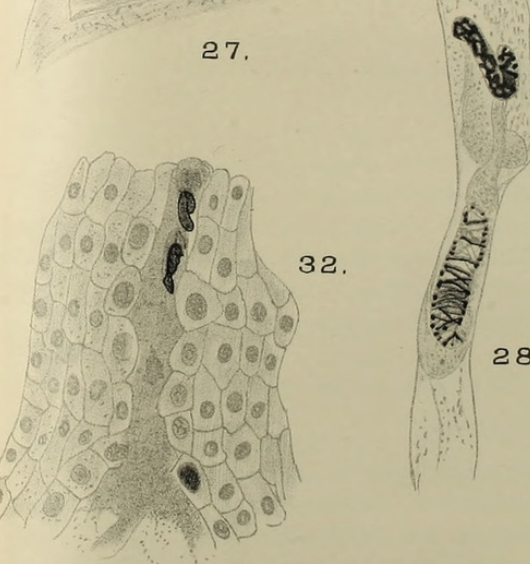

28. 


\section{$2 \mathrm{BHL}$ Biodiversity Heritage Library}

Welsford, E. J. 1914. "The genesis of the male nuclei in Lilium." Annals of botany 28, 265-270. https://doi.org/10.1093/oxfordjournals.aob.a089503.

View This Item Online: https://www.biodiversitylibrary.org/item/236856

DOI: https://doi.org/10.1093/oxfordjournals.aob.a089503

Permalink: https://www.biodiversitylibrary.org/partpdf/320021

\section{Holding Institution}

Smithsonian Libraries

\section{Sponsored by}

Biodiversity Heritage Library

\section{Copyright \& Reuse}

Copyright Status: Not in copyright. The BHL knows of no copyright restrictions on this item.

This document was created from content at the Biodiversity Heritage Library, the world's largest open access digital library for biodiversity literature and archives. Visit BHL at https://www.biodiversitylibrary.org. 